\title{
Cerrahi Aydınlatılmış Onam Hakkında Hastaların Bilgi Düzeyinin İncelenmesi
}

\author{
Examination of the Patients' Information Levels about Surgical \\ Informed Consent
}

\section{Zeynep KARAMAN ÖZLÜa, Münevver KILIÇ ${ }^{b}$, Ayşegül YAYLA}

ÖZET Amaç: Araştırma cerrahi aydınlatılmış onam hakkında hastaların bilgi düzeylerinin belirlenmesi amacıyla tanımlayıcı olarak yapıldı. Materyal ve Metot: Araştırmanın evrenini, Ekim-Aralık 2013 tarihleri arasında bir üniversite hastanesinin cerrahi kliniklerinde yatan hastalar oluşturdu. Örneklemine ise belirtilen tarihler arasında araştırma kriterlerine uyan, araştırmaya katılmayı kabul eden, iletişim kurulabilen, 18 yaş ve üzeri 200 hasta alındı. Veriler araştırmacı tarafından hastanın taburcu olmasına karar verildiği gün, hastanın uygun olduğu zamanda, araştırmacı tarafından hazırlanan anket formu kullanılarak yüz yüze görüşme yöntemiyle toplandı. İstatistiksel değerlendirmede; yüzdelik dağılım, ortalamalar ve Ki-kare testi kullanıldı. Bulgular: Aydınlatılmış onamı hastaların çoğunluğunun kendisinin okuduğu (\%54.5), onamı anlamadığı (\%70.0), onam için hemşire tarafindan imza alındığı (\%55.5), onamın formalite olduğunu düşündüğü (\%60.0) ve onam hakkında açıklama yapıldığ1 (\%54.5) belirlendi. Aydınlatılmış onamı çoğunlukla 31-43 yaş aralığında olan (\%35.0), kadın (\%53.3), lise mezunu (\%31.7), ev hanımı veya emekli (\%41.7), ilde yaşayan (\%53.3), daha önce 1 kez hastanede yatan $(\% 63.3)$ ve ameliyat olmayan (\%70.0) hastaların anladığı belirlendi. Cerrahi aydınlatılmış onamı okuyanların anlamadığı (\%62.4) ve okumayanların formalite olduğu için imzaladıkları (75.8), onamı okuyanların onamı anladı̆̆ (\% 68.3), onamı anlayanlara açıklama yapıldığı (\%75.0), onamı anlayanların önerisinin olmadığı (\%65.0) saptandı (p<0.05). Sonuç; Hastaların cerrahi aydınlatılmış onamı okuduğu ve anlamadığı, onam imzasının hemşireler tarafindan alındığı, açıklamanın hemşireler tarafından yapıldığı, onamı formalite olduğu için imzaladığı saptandı. Bu sonuçlar doğrultusunda, aydınlatılmış onamın uygulanmasıyla ilgili sorunların tanımlanması ve çözümüne yönelik kurumsal stratejilerin oluşturulması önerilebilir.

Anahtar Kelimeler: Aydınlatma, bilgilendirme, hasta, onam

\begin{abstract}
Aim: The purpose of this study was to determine the knowledge levels of patients regarding the surgical informed consent. Material and Method: The population of the study consisted of patients hospitalized in the surgical clinics of a university hospital between October and December 2013. The sample group consisted of 200 patients aged 18 and older who met the study criteria between the specified dates, agreed to accept in the study, and were able to communicate. The data were obtained through face-to-face interview method by using questionnaire prepared by the researcher when convenient on the day for which the researcher decided for discharge of the patient. Percentage distribution, mean, and chi-square test were used in order to conduct the statistical evaluation. Results: It was determined that majority of the patients read the informed consent themselves $(54.5 \%)$, they could not understand the informed consent $(70.0 \%)$, nurses took signatures for the consent $(55.5 \%)$, they thought that the consent was a formality $(60.0 \%)$, and an explanation about the consent was made $(54.5 \%)$. It was found that the informed consent was understood mostly by the patients who were in the age range of 31-43 years (35.0\%), women (53.3\%), high school graduate (31.7\%), housewife or retired $(41.7 \%)$, lived in the province $(53.3 \%)$, were hospitalized at hospital once before $(63.3 \%)$ and did not undergo any surgery $(70.0 \%)$. It was found that the rate of those who read and did not understand the surgical informed consent was $62.4 \%$ and those not reading the informed consent signed it $(75.8 \%)$ since it is a formality, those reading the consent understood it $(68.3 \%)$, an explanation was made to those understanding the consent $(75.0 \%)$ and those understanding the consent had no suggestion $(65.0 \%)(\mathrm{p}<0.05)$. Conclusion: It was determined that the patients read but did not understand the surgical informed consent, signature of the consent was taken by nurses, the explanations were made by nurses and they signed the consent since it is a formality. In line with these results, it could be recommended to identify problems related to implementation of the informed consent and make institutional strategies for their solutions.
\end{abstract}

Key words: Informing, briefing, patient, consent

\footnotetext{
a Yrd. Doç. Dr.,.Atatürk Üniversitesi Sağl1k Bilimleri Fakültesi, Hemşirelik Bölümü, Kampüs/ Erzurum, e-mail: zynp_krmnzl@hotmail.com Tlf: + (90) 4422312314

b Hemşire, Sağlık Bakanlığı - Ordu Üniversitesi Eğitim Ve Araştırma Hastanesi, mnvvvrklc_ordu@ @otmail.com Tlf: + (90) 4522250185

c Araş. Gör., Atatürk Üniversitesi Sağlık Bilimleri Fakültesi, Hemşirelik Bölümü, Kampüs/ Erzurum, e-mail: ayseguul21@hotmail.com, Tlf: + (90) 4422312364
} 


\section{Giriş}

Günümüzde sağlık alanında etik konuların öneminin artmasıyla birlikte hastanın bakıma katılımı da güncel bir hale gelmiştir ${ }^{1}$. Hastalara kendi bedenlerini kontrol etme hakkı veren, aydınlatılmış onam; bireyin kendi bedenine yapılacak olan her türlü tıbbi uygulamayı bilme ve belirleme hakkına sahip olduğu görüşünü temel alan ve kişinin hastalık anında da kişilik haklarını koruyabilmek için bu konuda düzenlenmiş yasalarla güvence altına alınmış olan bir kavramı ifade etmektedir. ${ }^{2}$ Aydınlatılmış onam, tıbbi etiğin temel ilkelerinden özerklik ilkesine dayanmaktadır. Özerklik, bir kişi ya da topluluğun kendisine ilişkin konularda, kendi değerlerine dayanarak kararlar vermesi ve bunları uygulamak üzere eylemlerde bulunması olarak tanımlanmaktadır. ${ }^{2-4}$ Bunun bir uzantısı olarak özerk kişinin, kendi sağlığına ilişkin tüm kararlara katılması sağlanmalıdır. "Aydınlatılmış onam"; hekim tarafından hastaya; hastalığının tanısı, tedavisi için uygulanması gereken tıbbi tedavi, tedavinin yapıs1, içerdiği riskleri, eğer işlem yapılmazsa hastalığının gidişatı için yapılan açıklamaları yeterince anladığı bu aydınlatmaya dayanarak, hiçbir baskı altında kalmadan, serbest iradesiyle, önerilen tıbbi uygulamayı, bilinçli ve gönüllü olarak kabul etmesi, şeklinde tanımlanabilir. ${ }^{5-7}$ Aydınlatılmış onamda temel amaç hastaya bilgi vermek ve hastanın bu bilgiyi anlamasını sağlamaktır. $\mathrm{Bu}$ nedenle formun imzalatılmasindan önce yapılması gereken, hastanın kendi kültürüne ve eğitim düzeyine uygun biçimde bilgilendirilmesinin sağlanmasıdır. Ayrıca hastanın verilen bilgileri anlamasının sağlanması ve anladığının denetlenmesi de gereklidir. ${ }^{2}$

Sağlık çalışanları arasında yaygın olan hastanın ayrıntılı bilgilendirilmesine gerek olmadığı görüşünün ardında, hastayı olas1 riskler hakkında bilgilendirmenin genellikle hastada kayg1 yaratacağ1 yönündeki düşünce yatmaktadır. Ancak, hastaya ayruntılı bilgi vermenin kayg1 yaratmadığı veya kaygıyı artırmadığı çeşitli araştırmacılar tarafindan gösterilmiştir. ${ }^{5,6}$ İnsanı "insan" yapan en önemli özellik olan kendi kaderini tayin hakkının sağlık alanında yaşama geçirilmesi, kişinin tam anlamiyla bilgilendirilmesi ve kendisi hakkında verilmesi gereken tüm kararlara katılmasının sağlanması önemlidir. ${ }^{6,8}$ Hasta bireyin haklarının korunup gözetilmesi hemşire ve doktorun görev alanı içerisinde yer alır. ${ }^{9}$ Hekim başına düşen hasta sayısının çokluğu, bunun bir sonucu olarak hekimlerin hastalara ayırdıkları sürenin kisitlılığ 1 , hastaların sosyo-kültürel düzeyleri, tıbbi açıklamaların anlaşılmasındaki güçlükler gibi bir takım olumsuzluklar, aydinlatılma ve aydınlatılmış onam konularına daha çok eğilmek gerekliliğini ortaya çıkarmıştır. ${ }^{10}$ Aydınlatılmış onam konusunda ülkemizde sınırlı sayıda araştırma yapılmıştır. ${ }^{1,10,11} \mathrm{Bu}$ çalışma ile aydınlatılmış onamın uygulanma durumu belirlenerek, hastaların onam hakkında bilgileri ve önerileri değerlendirilerek hekim ve hemşirenin desteklenmesine yönelik gerekli eğitim ve girişimlerin yapılmasıyla hastanın bilgilenmesinin artmasina ve bu konuda eksikliklerin giderilmesine katkı sağlanabileceği düşünüldü. $\mathrm{Bu}$ araştırma, hastaların aydınlatılmış onam hakkında bilgilerinin belirlenmesi amaciyla planlandi.

\section{Materyal ve Metot}

Tanımlayıcı türde olan araştırmanın evrenini, Ekim-Aralık 2013 tarihleri arasında bir Eğitim Araştırma Hastanesi Cerrahi Servisinde yatan 235 hasta oluşturdu. Örnekleme ise araştırmaya katılmayı kabul eden, iletişim kurulabilen, 18 yaş ve üzeri 200 hasta dahil edildi (Katılım oranı \%85). Veriler hastalarla yüz yüze görüşülerek toplandı.

Verilerin toplanmasında; literatür doğrultusunda hazırlanan ${ }^{6,9,11}$ hastaların tanıtıcı özelliklerini, aydınlatılmış onam hakkındaki bilgi düzeyi ve düşüncelerini içeren "Anket Formu" kullanıldı. Anket 
formunda, hastaların sosyo demografik ( yaş, cinsiyet, eğitim durumu, meslek, yaşanılan yer, hastaneye yatış sıklığı, önceden ameliyat olma durumu) ve onamla ilgili özelliklerini içeren (cerrahi aydınlatılmış onamı okuma durumu, cerrahi aydınlatılmış onamı anlama durumu, cerrahi aydınlatılmış onamı imzalayan kişi, cerrahi aydınlatılmış onama imzasını alan kişi, cerrahi aydınlatılmış onamı imzalama nedenini bilme durumu, cerrahi aydınlatılmış onam hakkında açıklama yapılma durumu, cerrahi aydınlatılmış onam hakkında açıklama yapan kişi, cerrahi aydınlatılmış onam hakkındaki önerileriniz) toplam 15 kapalı uçlu soru bulunmaktadır.

Araştırma verileri, araştırmacı tarafindan 08:00-16:00 ve 16:00-08:00 çalışma saatleri içerisinde, araştırmanın amacı hakkında bilgilendirilip sözel olarak izinleri alındıktan sonra yüz yüze görüşme yöntemi ile elde edildi. Veri toplama formlarının uygulanması yaklaşık 4 dakika sürdü.

Verilerin değerlendirilmesinde; yüzdelik dağılım, ortalama ve ki-kare testi kullanıldı. Anlamlılık seviyesi $\mathrm{p}=0.05$ olarak belirlendi.

Araştırmaya başlamadan önce araştırmanın yapılacağı kliniklerden yazılı izinler ve etik kurul onayı alındı.

\section{Bulgular}

Araştırma kapsamına alınan hastaların sosyo-demografik özellikleri incelendiğinde (Tablo 1), hastaların çoğunluğunun 31-43 yaş aralığında (\%36.0), lise mezunu (\%35.0), ev hanımı veya emekli olduğu (\%40.5), ilde yaşadığ (\%47.0), bir kez hastanede yattığı (\%49.5), daha önceden ameliyat öyküsünün olmadığ 1 (\%67.5) saptand1.

Tablo 1. Hastaların sosyo-demografik özelliklerinin dağılımı

\begin{tabular}{lcc}
\hline Özellikler & $\mathbf{n}$ & \% \\
\hline Yaş & 51 & 25.5 \\
$18-30$ & 72 & 36.0 \\
$31-43$ & 54 & 27.0 \\
$44-56$ & 23 & 11.5 \\
57 ve üstü & & \\
\hline Cinsiyet & 100 & 50.0 \\
Erkek & 100 & 50.0 \\
Kadın & & \\
\hline Eğitim Durumu & 32 & 16.0 \\
Okur - Yazar & 55 & 27.5 \\
İlköğretim & 70 & 35.0 \\
Lise & 43 & 21.5 \\
Üniversite & & \\
\hline Meslek & 32 & 16.0 \\
İşçi & 42 & 21.0 \\
Memur & 21 & 10.5 \\
Çiftçi & 24 & 12.0 \\
Esnaf & 81 & 40.5 \\
Ev hanımı+Emekli & & \\
Yaşanılan Yer & 94 & 47.0 \\
İl & 66 & 33.0 \\
İlçe & 40 & 20.0 \\
Köy & & \\
\hline Hastaneye Yatış Sıklığı & 99 & 49.5 \\
1 kez & 61 & 30.5 \\
2 kez & 40 & 20.0 \\
3 ve üstü & & \\
\hline Önceden Ameliyat Olma Durumu & 65 & 67.5 \\
Olan & 135 & \\
Olmayan & & \\
\hline
\end{tabular}


Tablo 2. Hastaların onam ile ilgili özelliklerinin dağılımı

\begin{tabular}{lcc}
\hline Özellikler & $\mathbf{n}$ & $\boldsymbol{\%}$ \\
\hline Cerrahi Aydınlatılmış Onamı Okuma Durumu & & \\
Okuyan & 109 & 54.5 \\
Okumayan & 91 & 45.5 \\
\hline Cerrahi Aydınlatılmış Onamı Anlama Durumu & 60 & 30.0 \\
Anladım & 140 & 70.0 \\
Anlamadım & & \\
\hline Cerrahi Aydınlatılmış Onamı İmzalayan Kişi & 170 & 85.0 \\
Hasta & 30 & 15.0 \\
Yakını & & \\
\hline Cerrahi Aydınlatılmış Onama İmzasını Alan Kişi & 111 & 55.5 \\
Hemşire & 56 & 28.0 \\
Doktor & 33 & 16.5 \\
Sekreter & & \\
\hline Cerrahi Aydınlatılmış Onamı İmzalama Nedenini & & \\
Bilme Durumu & 80 & 40.0 \\
Bilen & 120 & 60.0 \\
Bilmeyen (formalite olduğunu düşünen) & & \\
\hline Cerrahi Aydınlatılmış Onam Hakkında Açıklama & 109 & 54.5 \\
Yapılma Durumu & 91 & 45.5 \\
Yapılan & & \\
Yapılmayan & 65 & 59.7 \\
\hline Cerrahi Aydınlatılmış Onam Hakkında Açıklama & 39 & 35.7 \\
Yapan Kişi & 5 & 4.6 \\
Hemşire & 109 & 54.5 \\
Doktor & 26 & 13.0 \\
Sekreter & 21 & 10.5 \\
\hline Cerrahi Aydınlatılmış Onam Hakkındaki Önerileriniz & 44 & 22.0 \\
\hline Önerisi olmayan & &
\end{tabular}

Hastaların onam ile ilgili özelliklerinin dağılımı Tablo 2'de görülmektedir. Hastaların cerrahi aydınlatılmış onamı okuduğu $(\% 54.5)$ ve anlamadığ $1 \quad$ (\%70.0), onamı hastanın kendisinin imzaladığ 1 (\%85.0), onam imzasının hemşireler tarafından alındığ
(\%55.5), onamı imzalama nedenini bilmediği (formalite olduğunu düşündüğü) (\%60.0), onam hakkında açıklama yapıldığ 1 (\%54.5), açıklamanın hemşireler tarafından yapıldığ 1 (\%59.7), onam hakkında önerisinin olmadığ $1(\% 54.5)$ tespit edildi. 
Tablo 3. Hastaların sosyo-demografik özelliklerine göre cerrahi aydınlatılmış onamı okuma durumunun karşılaştırılması

\begin{tabular}{|c|c|c|c|c|c|c|c|}
\hline \multirow{3}{*}{ Özellikler } & \multicolumn{6}{|c|}{ Cerrahi Aydınlatılmış Onamı Okuma Durumu } & \multirow{3}{*}{$\begin{array}{c}\text { Test ve p } \\
\text { değeri }\end{array}$} \\
\hline & \multicolumn{2}{|c|}{ Okuyan } & \multicolumn{2}{|c|}{ Okumayan } & \multicolumn{2}{|c|}{ Toplam } & \\
\hline & $\mathbf{n}$ & $\%$ & $\mathbf{n}$ & $\%$ & $\mathbf{n}$ & $\%$ & \\
\hline \multicolumn{8}{|l|}{ Yaş } \\
\hline $18-30$ & 34 & 31.2 & 17 & 18.7 & 51 & 25.5 & \multirow{4}{*}{$\begin{array}{c}\mathbf{X}^{\mathbf{2}}=13.05 \\
\mathrm{df}=3 \\
\mathbf{p}<\mathbf{0 . 0 5}\end{array}$} \\
\hline $31-43$ & 40 & 36.7 & 32 & 35.2 & 72 & 36.0 & \\
\hline $44-56$ & 30 & 27.5 & 24 & 26.4 & 54 & 27.0 & \\
\hline 57 ve üstü & 5 & 4.6 & 18 & 19.8 & 23 & 11.5 & \\
\hline Cinsiyet & & & & & & & $\mathbf{X}^{2}=0.18$ \\
\hline Erkek & 56 & 56.0 & 44 & 44.0 & 100 & 100.0 & $\mathrm{df}=1$ \\
\hline Kadin & 53 & 53.0 & 47 & 47.0 & 100 & 100.0 & $\mathrm{p}>0.05$ \\
\hline \multicolumn{8}{|l|}{ Eğitim Durumu } \\
\hline Okur - Yazar & 3 & 2.8 & 29 & 31.9 & 32 & 16.0 & \multirow{4}{*}{$\begin{array}{c}\mathbf{X}^{\mathbf{2}}=56.59 \\
\mathrm{df}=3 \\
\mathbf{p}<\mathbf{0 . 0 5}\end{array}$} \\
\hline İlköğretim & 21 & 19.3 & 34 & 37.4 & 55 & 27.5 & \\
\hline Lise & 47 & 43.1 & 23 & 25.3 & 70 & 35.0 & \\
\hline Üniversite & 38 & 34.9 & 5 & 5.5 & 43 & 21.5 & \\
\hline \multicolumn{8}{|l|}{ Meslek } \\
\hline İşçi & 20 & 18.3 & 12 & 13.2 & 32 & 16.0 & \multirow{5}{*}{$\begin{array}{c}\mathbf{X}^{\mathbf{2}}=31.78 \\
\mathrm{df}=4 \\
\mathbf{p}<\mathbf{0 . 0 5}\end{array}$} \\
\hline Memur & 35 & 32.1 & 7 & 7.7 & 42 & 21.0 & \\
\hline Çiftçi & 6 & 5.5 & 15 & 16.5 & 21 & 10.5 & \\
\hline Esnaf & 17 & 15.6 & 7 & 7.7 & 24 & 12.0 & \\
\hline Ev hanımı+Emekli & 31 & 28.4 & 50 & 54.9 & 81 & 40.5 & \\
\hline \multicolumn{8}{|l|}{ Yaşanılan Yer } \\
\hline İl & 69 & 63.3 & 25 & 27.5 & 94 & 47.0 & \multirow{3}{*}{$\begin{array}{c}\mathbf{X}^{\mathbf{2}}=31.57 \\
\mathrm{df}=2 \\
\mathbf{p}<\mathbf{0 . 0 5}\end{array}$} \\
\hline İlçe & 31 & 28.4 & 35 & 38.5 & 66 & 33.0 & \\
\hline Köy & 9 & 8.3 & 31 & 34.0 & 40 & 20.0 & \\
\hline \multicolumn{7}{|l|}{ Hastaneye Yatış Sıklığı } & \multirow{4}{*}{$\begin{array}{c}\mathbf{X}^{\mathbf{2}}=18.90 \\
\mathrm{df}=2 \\
\mathbf{p}<\mathbf{0 . 0 5}\end{array}$} \\
\hline $1 \mathrm{kez}$ & 68 & 62.4 & 31 & 34.1 & 99 & 49.5 & \\
\hline $2 \mathrm{kez}$ & 29 & 26.6 & 32 & 35.2 & 61 & 30.5 & \\
\hline 3 ve üstü & 12 & 11.0 & 28 & 30.7 & 40 & 20.0 & \\
\hline \multicolumn{7}{|l|}{ Önceden Ameliyat Olma Durumu } & $\mathbf{X}^{2}=1.07$ \\
\hline Olan & 32 & 29.4 & 33 & 36.3 & 65 & 32.5 & $\mathrm{df}=1$ \\
\hline Olmayan & 77 & 70.6 & 58 & 63.7 & 135 & 67.5 & $p>0.05$ \\
\hline
\end{tabular}

Aydınlatılmış onamı çoğunlukla 3143 yaş aralığında olan (\%36.7), erkek (\%56.0), lise mezunu (\%43.1), memur (\%32.1), ilde yaşayan (\%63.3), $1 \mathrm{kez}$ hastanede yatan (\%62.4) ve ameliyat olmayan (\%70.6) hastaların okuduğu belirlendi. Hastaların cerrahi aydınlatılmış onamı okuma durumu ile yaş, eğitim durumu, meslek, yaşanılan yer ve hastaneye yatış sıklığı arasında istatistiksel olarak anlamlı fark saptanırken $(\mathbf{p}<\mathbf{0 . 0 5})$, cinsiyet ve önceden ameliyat olma durumu arasinda istatistiksel olarak anlamlı fark olmadiğ 1 saptand $1 \quad(p>0.05)$ (Tablo3). 31-43 yaş aralığında, ilde yaşayanların, bir kez hastanede yatanların onamı çoğunlukla okuduğu, ev hanımı-emeklilerin onamı çoğunlukla okumadığı belirlendi. 
Tablo 4. Hastaların onam ile ilgili özelliklerine göre cerrahi aydınlatılmış onamı okuma durumunun karşılaştırılması

\begin{tabular}{|c|c|c|c|c|c|c|c|}
\hline \multirow{3}{*}{ Özellikler } & \multicolumn{6}{|c|}{ Cerrahi Aydınlatılmış Onamı Okuma Durumu } & \multirow{3}{*}{$\begin{array}{l}\text { Test ve p } \\
\text { değeri }\end{array}$} \\
\hline & \multicolumn{2}{|c|}{ Okuyan } & \multicolumn{2}{|c|}{ Okumayan } & \multicolumn{2}{|c|}{ Toplam } & \\
\hline & $\mathbf{n}$ & $\%$ & $\mathbf{n}$ & $\%$ & $\mathbf{n}$ & $\%$ & \\
\hline \multicolumn{8}{|l|}{ Cerrahi Aydınlatılmış Onamı } \\
\hline Anlama Durumu & & & & & & & $\mathbf{X}^{2}=6.61$ \\
\hline Anladım & 41 & 37.6 & 19 & 20.9 & 60 & 30.0 & $\mathrm{df}=1$ \\
\hline Anlamadım & 68 & 62.4 & 72 & 79.1 & 140 & 70.0 & $\mathrm{p}<0.05$ \\
\hline \multicolumn{8}{|l|}{ Cerrahi Aydınlatılmış Onamı } \\
\hline Hasta & 97 & 89.0 & 73 & 80.2 & 170 & 85.0 & $\mathrm{df}=1$ \\
\hline Hasta yakını & 12 & 11.0 & 18 & 19.8 & 30 & 15.0 & $\mathrm{p}>0.05$ \\
\hline \multicolumn{8}{|l|}{ Cerrahi Aydınlatılmış Onama } \\
\hline Hemşire & 60 & 55.0 & 51 & 56.0 & 111 & 55.5 & $\mathbf{X}^{2}=1.97$ \\
\hline Doktor & 34 & 31.2 & 22 & 24.2 & 56 & 28.0 & $\mathrm{df}=2$ \\
\hline Sekreter & 15 & 13.8 & 18 & 19.8 & 33 & 16.5 & $\mathrm{p}>0.05$ \\
\hline \multicolumn{8}{|l|}{$\begin{array}{l}\text { Cerrahi Aydınlatılmış Onamı } \\
\text { İmzalama Nedenini Bilme }\end{array}$} \\
\hline $\begin{array}{l}\text { Durumu } \\
\text { Bilen }\end{array}$ & 58 & 53.3 & 22 & 24.2 & 80 & 40.0 & $\mathbf{X}^{2}=24.55$ \\
\hline $\begin{array}{l}\text { Bilmeyen (formalite olduğunu } \\
\text { düşünen) }\end{array}$ & 51 & 46.7 & 69 & 75.8 & 120 & 60.0 & $\begin{array}{c}\mathrm{df}=3 \\
\mathbf{p}<\mathbf{0 . 0 5}\end{array}$ \\
\hline \multicolumn{8}{|l|}{ Cerrahi Aydınlatılmış Onam } \\
\hline $\begin{array}{l}\text { Hakkında Açıklama Yapılma } \\
\text { Durumu }\end{array}$ & & & & & & & $\mathbf{X}^{2}=2.54$ \\
\hline Yapilan & 65 & 59.6 & 44 & 48.4 & 109 & 54.5 & $\mathrm{df}=1$ \\
\hline Yap1lmayan & 44 & 40.4 & 47 & 51.6 & 91 & 45.5 & $\mathrm{p}>0.05$ \\
\hline \multicolumn{8}{|l|}{ Cerrahi Aydınlatılmış Onam } \\
\hline \multicolumn{8}{|l|}{ Hakkında Açıklama Yapan Kişi } \\
\hline Hemşire & 34 & 43.1 & 31 & 25.0 & 65 & 59.7 & $\mathbf{X}^{2}=3.84$ \\
\hline Doktor & 28 & 52.3 & 11 & 70.5 & 39 & 35.7 & $\mathrm{df}=2$ \\
\hline Sekreter & 3 & 4.6 & 3 & 4.5 & 5 & 4.6 & $\mathrm{p}>0.05$ \\
\hline \multicolumn{8}{|l|}{ Cerrahi Aydınlatılmış Onam } \\
\hline Önerisi olmayan & 54 & 49.5 & 55 & 60.4 & 109 & 54.5 & \\
\hline Daha açıklayıcı bilgiler yazılmalı & 17 & 15.6 & 9 & 9.9 & 26 & 13.0 & $X^{2}=3.19$ \\
\hline Daha sade bir dille yazılmalı & 11 & 10.1 & 10 & 11.0 & 21 & 10.5 & $\mathrm{dt}=3$ \\
\hline Aceleyle imzalatılmamalı & 27 & 24.8 & 17 & 18.7 & 44 & 22.0 & $\mathrm{p}>0.05$ \\
\hline
\end{tabular}

Hastaların onam ile ilgili özelliklerine göre cerrahi aydınlatılmış onamı okuma durumunun karşılaştırılması Tablo 4'de görülmektedir. Aydınlatılmış onamı okuyan hastaların çoğunluğunun, onamı anlamadığ 1 (\%37.6), kendisinin okuduğu (\%89.0), hemşire tarafindan imza alındığı (\%55.0), onamı imzalama nedenini bilmediği (formalite olduğunu düşündüğü) (\%46.7), onam hakkında açıklama yapıldığı
(\%59.6), açıklamayı doktorun yaptığ (\%52.3) ve bu konuda önerisinin olmadığ (\%49.5) belirlendi. Hastaların cerrahi aydınlatılmış onamı okuma durumu ile onamı anlama durumu ve onamı imzalama nedenini bilme durumu arasinda istatistiksel olarak anlamlı fark saptand $1 \quad(\mathbf{p}<\mathbf{0 . 0 5})$. Onamı okuyanların çoğunluğunun anlamadığı, okumayanların çoğunluğunun 
onamın formalite olduğunu düşündüğü belirlendi.

Tablo 5. Hastaların sosyo-demografik özelliklerine göre cerrahi aydınlatılmış onamı anlama durumunun karşılaştırılması

\begin{tabular}{|c|c|c|c|c|c|c|c|}
\hline \multirow{3}{*}{ Özellikler } & \multicolumn{6}{|c|}{ Cerrahi Aydınlatılmış Onamı Anlama Durumu } & \multirow{3}{*}{$\begin{array}{c}\text { Test ve p } \\
\text { değeri }\end{array}$} \\
\hline & \multicolumn{2}{|c|}{ Anlayan } & \multicolumn{2}{|c|}{ Anlamayan } & \multicolumn{2}{|c|}{ Toplam } & \\
\hline & $\mathbf{n}$ & $\%$ & $\mathbf{n}$ & $\%$ & $\mathbf{n}$ & $\%$ & \\
\hline \multicolumn{8}{|l|}{ Yaş } \\
\hline $18-30$ & 19 & 31.7 & 32 & 22.9 & 51 & 25.5 & \multirow{4}{*}{$\begin{array}{c}\mathbf{X}^{2}=3.10 \\
\mathrm{df}=3 \\
\mathrm{p}>0.05\end{array}$} \\
\hline $31-43$ & 21 & 35.0 & 51 & 36.4 & 72 & 36.0 & \\
\hline $44-56$ & 12 & 20.0 & 42 & 30.0 & 54 & 27.0 & \\
\hline 57 ve üstü & 8 & 13.3 & 15 & 10.7 & 23 & 11.5 & \\
\hline Cinsiyet & & & & & & & $\mathbf{X}^{2}=0.18$ \\
\hline Erkek & 28 & 46.7 & 72 & 51.4 & 100 & 100.0 & $\mathrm{df}=1$ \\
\hline Kadın & 32 & 53.3 & 68 & 48.6 & 100 & 100.0 & $\mathrm{p}>0.05$ \\
\hline \multicolumn{8}{|l|}{ Eğitim Durumu } \\
\hline Okur - Yazar & 11 & 18.3 & 21 & 15.0 & 32 & 16.0 & \multirow{4}{*}{$\begin{array}{c}\mathbf{X}^{2}=3.48 \\
\mathrm{df}=3 \\
\mathrm{p}>0.05\end{array}$} \\
\hline İlköğretim & 13 & 21.7 & 42 & 30.0 & 55 & 27.5 & \\
\hline Lise & 19 & 31.7 & 51 & 36.4 & 70 & 35.0 & \\
\hline Üniversite & 17 & 28.3 & 26 & 18.6 & 43 & 21.5 & \\
\hline \multicolumn{8}{|l|}{ Meslek } \\
\hline İşçi & 7 & 11.7 & 25 & 17.9 & 32 & 16.0 & \multirow{5}{*}{$\begin{array}{c}\mathbf{X}^{2}=8.74 \\
\mathrm{df}=4 \\
\mathrm{p}>0.05\end{array}$} \\
\hline Memur & 15 & 25.0 & 27 & 19.3 & 42 & 21.0 & \\
\hline Çiftçi & 2 & 3.3 & 19 & 13.6 & 21 & 10.5 & \\
\hline Esnaf & 11 & 18.3 & 13 & 9.3 & 24 & 12.0 & \\
\hline Ev hanımı+Emekli & 25 & 41.7 & 56 & 40.0 & 81 & 40.5 & \\
\hline \multicolumn{8}{|l|}{ Yaşanılan Yer } \\
\hline İl & 32 & 53.3 & 62 & 44.3 & 94 & 47.0 & \multirow{3}{*}{$\begin{array}{c}\mathbf{X}^{2}=1.44 \\
\mathrm{df}=2 \\
\mathrm{p}>0.05\end{array}$} \\
\hline İlçe & 18 & 30.0 & 48 & 34.3 & 66 & 33.0 & \\
\hline Köy & 10 & 16.7 & 30 & 21.4 & 40 & 20.0 & \\
\hline \multicolumn{8}{|l|}{ Hastaneye Yatış Sıklığı } \\
\hline $1 \mathrm{kez}$ & 38 & 63.3 & 61 & 43.6 & 99 & 49.5 & \multirow{3}{*}{$\begin{array}{c}\mathbf{X}^{\mathbf{2}}=\mathbf{7 . 1 4} \\
\mathrm{df}=2 \\
\mathbf{p}<\mathbf{0 . 0 5}\end{array}$} \\
\hline $2 \mathrm{kez}$ & 15 & 25.0 & 46 & 32.9 & 61 & 30.5 & \\
\hline 3 ve üstü & 7 & 11.7 & 33 & 23.6 & 40 & 20.0 & \\
\hline Önceden Ameliyat Olma Durumu & & & & & & & $\mathrm{X}^{2}=0.24$ \\
\hline Olan & 18 & 30.0 & 47 & 33.6 & 65 & 32.5 & $\mathrm{df}=1$ \\
\hline Olmayan & 42 & 70.0 & 93 & 66.4 & 135 & 67.5 & $p>0.05$ \\
\hline
\end{tabular}

Hastalarin sosyo-demografik özelliklerine göre cerrahi aydınlatılmış onamı anlama durumu karşılaştırıldığında (Tablo 5), aydınlatılmış onamı çoğunlukla 31-43 yaş aralığında olan (\%35.0), kadın (\%53.3), lise mezunu (\%31.7), ev hanımı veya emekli (\%41.7), ilde yaşayan (\%53.3), $1 \mathrm{kez}$ hastanede yatan (\%63.3) ve ameliyat olmayan (\%70.0) hastaların anladığ belirlendi. Hastaların cerrahi aydınlatılıış onamı anlama durumu ile hastaneye yatış sıklığı arasında istatistiksel olarak anlamlı fark saptanırken $(\mathbf{p}<\mathbf{0 . 0 5})$, yaş, cinsiyet, eğitim durumu, meslek, yaşanılan yer ve önceden ameliyat olma durumu arasinda istatistiksel olarak anlamlı fark olmadığ saptand 1 ( $>0.05)$. Onamı anlayanlarının çoğunluğunun hastanede yattı̆̆ belirlendi. 
Tablo 6. Hastaların onam ile ilgili özelliklerine göre cerrahi aydınlatılmış onamı anlama durumunun karşılaştırılması

\begin{tabular}{|c|c|c|c|c|c|c|c|}
\hline \multirow[b]{3}{*}{ Özellikler } & \multicolumn{6}{|c|}{ Cerrahi Aydınlatılmış Onamı Anlama Durumu } & \multirow{3}{*}{$\begin{array}{c}\text { Test ve } p \\
\text { değeri }\end{array}$} \\
\hline & \multicolumn{2}{|c|}{ Anlayan } & \multicolumn{2}{|c|}{ Anlamayan } & \multicolumn{2}{|c|}{ Toplam } & \\
\hline & $\mathbf{n}$ & $\%$ & $\mathbf{n}$ & $\%$ & $\mathbf{n}$ & $\%$ & \\
\hline \multicolumn{8}{|l|}{ Cerrahi Aydınlatılmıș Onamı } \\
\hline Okuma Durumu & & & & & & & $X^{2}=6.61$ \\
\hline Okuyan & 41 & 68.3 & 68 & 48.6 & 109 & 54.5 & $\mathrm{df}=1$ \\
\hline Okumayan & 19 & 31.7 & 72 & 51.4 & 91 & 45.5 & $\mathrm{p}<0.05$ \\
\hline \multicolumn{8}{|l|}{ Cerrahi Aydınlatılmıș Onamı } \\
\hline İmzalayan Kişi & & & & & & & $\mathbf{X}^{2}=0.18$ \\
\hline Hastanın kendisi & 50 & 83.3 & 120 & 85.7 & 170 & 85.0 & $\mathrm{df}=1$ \\
\hline Hasta yakını & 10 & 16.7 & 20 & 14.3 & 30 & 15.0 & $\mathrm{p}>0.05$ \\
\hline \multicolumn{8}{|l|}{ Cerrahi Aydınlatılmış Onama } \\
\hline \multicolumn{8}{|l|}{ İmzasını Alan Kiși } \\
\hline Hemşire & 38 & 63.3 & 73 & 52.1 & 111 & 55.5 & $\mathbf{X}^{2}=3.19$ \\
\hline Doktor & 16 & 26.7 & 40 & 28.6 & 56 & 28.0 & $\mathrm{df}=2$ \\
\hline Sekreter & 6 & 10.0 & 27 & 19.3 & 33 & 16.5 & $\mathrm{p}>0.05$ \\
\hline \multicolumn{8}{|l|}{ Cerrahi Aydınlatılmış Onamı } \\
\hline \multicolumn{8}{|l|}{ İmzalama Nedenini Bilme } \\
\hline Durumu & & & & & & & \\
\hline Bilen & 30 & 50.0 & 50 & 35.7 & 80 & 40.0 & $\mathrm{df}=3$ \\
\hline $\begin{array}{l}\text { Bilmeyen (formalite olduğunu } \\
\text { düşünen) }\end{array}$ & 30 & 50.0 & 90 & 64.3 & 120 & 60.0 & $\mathrm{p}>0.05$ \\
\hline \multicolumn{8}{|l|}{ Cerrahi Aydınlatılmış Onam } \\
\hline \multicolumn{8}{|l|}{ Hakkında Acıklama Yapılma } \\
\hline Durumu & & & & & & & $\mathbf{X}^{2}=14.52$ \\
\hline Yapılan & 45 & 75.0 & 64 & 45.7 & 109 & 54.5 & $\mathrm{df}=1$ \\
\hline Yap1lmayan & 15 & 25.0 & 76 & 54.3 & 91 & 45.5 & $\mathrm{p}<\mathbf{0 . 0 5}$ \\
\hline \multicolumn{8}{|l|}{ Cerrahi Aydınlatılmış Onam } \\
\hline \multicolumn{8}{|l|}{ Hakkında Açıklama Yapan Kişi } \\
\hline Hemşire & 29 & 64.4 & 36 & 56.3 & 65 & 59.7 & $\mathbf{X}^{2}=0.76$ \\
\hline Doktor & 14 & 31.1 & 25 & 39.1 & 39 & 35.7 & $\mathrm{df}=2$ \\
\hline Sekreter & 2 & 4.4 & 3 & 2.8 & 5 & 4.6 & $p>0.05$ \\
\hline \multicolumn{8}{|l|}{ Cerrahi Aydınlatılmış Onam } \\
\hline Hakkındaki Önerileriniz & & & & & & & \\
\hline Önerisi olmayan & 39 & 65.0 & 70 & 50.0 & 109 & 54.5 & $\mathbf{X}^{2}=7.92$ \\
\hline Daha açıklayıcı bilgiler yazılmalı & 2 & 3.3 & 24 & 17.1 & 26 & 13.0 & $\mathrm{df}=3$ \\
\hline Daha sade bir dille yazılmalı & 6 & 10.0 & 15 & 10.7 & 21 & 10.5 & $p<0.05$ \\
\hline Aceleyle imzalatılmamalı & 13 & 21.7 & 31 & 22.2 & 44 & 22.0 & \\
\hline
\end{tabular}

Hastaların onam ile ilgili özelliklerine göre cerrahi aydınlatılmış onamı anlama durumunun karşılaştırılması Tablo 6'da görülmektedir. Aydınlatılmış onamı anlayan hastaların çoğunluğunun, onamı okuduğu (\%68.3), kendisinin okuduğu (\%83.3), hemşire tarafindan imza alındiğ 1 (\%63.3), bunun formalite olduğu (\%50.0), onam hakkında açıklama yapıldığ 1 (\%75.0), açıklamayı hemşirenin yaptığ 1 (\%64.4) ve bu konuda önerisinin olmadığ
(\%65.0) belirlendi. Hastaların cerrahi aydınlatılmış onamı anlama durumu ile onamı okuma durumu, onam hakkında açıklama yapılma durumu ve onam hakkındaki öneriler durumu arasında istatistiksel olarak anlamlı fark saptand 1 $(\mathrm{p}<0.05)$. Onamı anlayanlarının çoğunluğunun onamı okuduğu, onamla ilgili açıklama yapıldığı ve onamla ilgili önerisinin olmadığı belirlendi. 


\section{Tartışma}

Her türlü tıbbi girişimden önce hastaların bilgilendirilmesi ve onamlarının alınması hem yasal hem de etik açıdan, kişinin özerkliğine saygı ilkesi ve hekimin görev ve sorumluluğunun gereği olarak günümüz tıp uygulamasının vazgeçilmez bir unsurudur. ${ }^{5}$ Genellikle hekimler aydınlatılmış onamı hastalık ve tedavi hakkında kişiyi ya da bir yakınını sözlü olarak kısaca bilgilendirmek gibi düşünmektedirler. ${ }^{8} \mathrm{Bu}$ mantık çerçevesinde hekim çoğu zaman hastası ile yüz yüze görüşme gereği bile duymamaktadır. Dolayısı ile hekimler bazen matbu bir form, bazen bilgisayar aracılığıyla bazen ise herhangi bir sağlık personeli aracılığ 1 ile bu işlemi yaptıktan sonra hasta ya da yakınının imzasını almayı yeterli görmektedir. ${ }^{12} \mathrm{Bu}$ bağlamda aydınlatılmış onamın uygulanma durumu ve hastaların onam hakkında bilgilerinin değerlendirilmesi önemlidir.

Çalışmada hastaların cerrahi aydınlatılmış onamı okuduğu $(\% 54.5)$ ve anlamadığı (\%70.0) tespit edildi. Jukic ve ark.nın $^{13}$ (2011) cerrahi hastalarının aydınlatılmış onam sürecini bilme durumuna ilişkin çalışmalarında, hastaların çoğunluğunun (\%70.2) "kısmen" yanıtını verdikleri belirlenmiş ve bu sonuç yeterli bilgiye sahip olmadıkları şeklinde yorumlanmıştır. Özcan' $1 n^{10}$ (2008) yaptığ1 çalışmada hastaların kendilerine aktarılan bilgileri anlamadiklarından fakat buna rağmen onam verdiklerinden bahsedilmektedir. Kalala'nın ${ }^{14}$ (2011) çalışmasında hastaların \%24'ünün aydınlatılmış onam formunu imzalamış olmalarına rağmen önemini bilmedikleri belirtilmiştir. $\mathrm{Bu}$ çalışmalar hastaların aydınlatılmış onam formunu imzalamış olsa bile öneminin ve içeriğinin farkında olmayabileceklerini düşündürmektedir.

Çalışmada onam imzasının hemşireler tarafindan alındığı (\%55.5), onam hakkında açıklama yapıldığı (\%54.5), açıklamanın hemşireler tarafindan yapıldiğ 1 (\%59.7) ve aceleyle imzalatılmaması (\%22.0) gerektiği belirlendi. Ertem ${ }^{1}$ ve ark. 'nın (2013) kardiyak cerrahi yapılan hastaların ameliyat öncesi verilen aydınlatılmış onam hakkındaki görüş ve önerilerinin belirlenmesi adlı çalışmasında hastaların onam imzasının \%76.1'inin hemşireler tarafından alındığı saptanmıştır. İncesu'nun ${ }^{11}$ (2014) çalışmasında aydınlatılmış onam alma sürecinde, hekimin yeterince aktif olmadığ çoğunlukla kendisinin imzalatmadığ imzalatma işleminin daha çok diğer sağlik çalışanları tarafından gerçekleştirildiği, hazırlanmış onam belgesinin hasta tarafindan okunması için uygun ortam-süre verilmediği ve hastanın onam hakkında aklına takılanları sorma firsatı bulamadığ 1 saptanmıştır. Tibbi müdahalelerin uygulanmasinda genel kabul, aydınlatmanın müdahaleyi uygulayacak hekim tarafindan yapilması ya da müdahalenin yürütülmesi sorumluluğunu alan hekimin yapması gerektiği görüşüdür. ${ }^{15}$ Aydın Er ve ark.'nın ${ }^{16}$ (2011) yaptıkları bir çalışmada aydınlatılmış onamın etik kural ve yönetmeliğe göre istendik düzeyde alınmadığ $\breve{1}_{1}$ sonucuna ulaşmışlardır. $\quad \mathrm{Bu}$ çalışmada da aydınlatılmış onamın uygulanışının hekim tarafindan istendik düzeyde yapılmadığ1 belirlenmiştir.

Çalışmada, cerrahi aydınlatılıış onamı okuyanların onamı anlamadığı ve onamı formalite olduğu için imzaladı $\breve{1}$ belirlendi. Literatürde belirtildiği gibi bilgilendirmenin hastanın anlama kapasitesine göre uygun yolla, açık ve anlaşılır, yabancı teknik ve terimlerden arındırılarak, şüpheye yer vermeyecek şekilde yapılması gerekmektedir. $^{10}$ İncesu'nun ${ }^{11}$ (2014) çalışmasında hastaların $\%$ 42,9'u hekimin onam içeriği hakkında açıklamaları yaptığı ancak hastanın onam belgesini okumadan hemşire aracılığı ile imzaladığını belirtmişlerdir. Literatürde, hastaların kendilerine aktarılan bilgileri anlamadıklarından fakat buna rağmen onam verdiklerinden bahsedilmektedir. ${ }^{14} \mathrm{Bu}$ çalışmada onamın anlaşılamaması, verilen bilginin hastanın anlama kapasitesine uygun olmamas1 ve yabanc1-teknik 
terminoloji kullanılmasından kaynaklandığ 1 düşünülebilir.

Cerrahi aydınlatılmış onamı anlayanların onamı okuduğu ve onam hakkında açıklama yapıldığ 1 saptandı. İncesu'nun ${ }^{11}$ (2014) çalışmasında hastaların\% 34,3 ' $\ddot{\mathrm{u}}$ hekimin gerekli açıklamaları yaptığı hastanın onam belgesini okuyarak ve ikna olarak imzaladığ 1 tespit edilmiştir. Ertem ve ark. ${ }^{1}$ (2013)'nın kardiyak cerrahi yapılan hastaların ameliyat öncesi verilen aydınlatılmış onam hakkındaki görüş ve önerilerinin belirlenmesi adlı çalışmasında hastaların sadece \% 60.9' unun anlatilanlar1 anlamasına rağmen, tamamına yakınının (\%92.4) formdaki her şeyi kabul ettikleri belirtilmiştir. Çalışma sonucu yapılan bu çalışmanın sonucuyla benzerlik göstermektedir.

Günümüzde değişen ve gelişen hasta - hekim ilişkisinin yasal zorunlulukları ile bunun vazgeçilmez unsuru olan “ Aydınlatılmış Onam” konusunda yeterli bilgiye sahip olmadiklarını göstermektedir. Turla ve ark. ${ }^{17}$ (2005) hastaların \%89,9'u "kendisine niçin ameliyat olması gerektiğinin açıklandığını", ancak bunların \%74,2'si "bu açılamayı tatmin edici düzeyde bulmadıklarını" ifade etmiştir. Hasta ve sağlam bireyler, sağlik durumunu, kendine uygulanacak tıbbi işlemleri, bunların faydalar1 ve olas1 riskleri, alternatif tedavi yöntemlerini, tedavinin kabul edilmemesi halinde ortaya çıkabilecek muhtemel sonuçları ve hastalığın seyri ve sonuçları konusunda sözlü veya yazılı olarak bilgi istemek hakkına sahiptir. Ancak hastalar

\section{Kaynaklar}

1. Ertem A, Yava A, Demirkılıç U. Kardiyak cerrahi yapılan hastaların ameliyat öncesi verilen aydınlatılmış onam hakkındaki görüş ve önerilerinin belirlenmesi. Türk Göğ̈̈s Kalp Damar halen doktor, hemşire ve diğer sağlik çalışanlarından cerrahi süreç hakkında yeterli bilgi alamamaktadır. ${ }^{2,9,18} \mathrm{Bu}$ durum aydınlatılmış onamın uygulanmasıyla ilgili sorunların var olduğunu göstermektedir.

\section{Sonuç ve Öneriler}

Çalışmada hastaların cerrahi aydınlatılmış onamı okuduğu ve anlamadığı, onam imzasının hemşireler tarafindan alındığg, açıklamanın hemşireler tarafından yapıldığı, onamı okuyanların onamı anlamadığı ve onamı formalite olduğu için imzaladığ 1 saptand. $\mathrm{Bu}$ sonuçlar doğrultusunda bireye anlatılanları anlayıp anlamadıği sorulmalı, kendi ifadesi ile tekrar ettirilip anlaşılmayan hususlar tekrar anlatılmalıdır. Hastalar bakımın bir parçası olarak ele alınmalı, hastaların sağlık durumu ve bakımı konusunda bilgilendirilmeleri ve işbirliği yetenekleri arttırılmadır. Sorunların önlenmesi için özellikle sağlık profesyonellerinin dikkat etmesi gereken hususların başında, hasta haklarına dair yasal mevzuatı en iyi şekilde öğrenmeli, hekim-hasta ilişkilerinde hastanın bireysel hakları gözetilmelidir. Aydınlatılmış onamın uygulanmasıyla ilgili sorunların tanımlanması ve çözümüne yönelik kurumsal stratejilerin oluşturulması ve kurum politikalarının geliştirilmesi sağlanmalıdır. Çalışanlara yönelik genel onam alma ve bilgilendirme hakk1 konularında hizmet içi programlar planlanmalıdır. Sağlık çalışanlarının bu uygulamayı davranış modeli haline getirmelerinin sağlanması için eğitim çalışmaları ve denetimin arttırılması da önerilebilir.

Cerrahisi Dergisi, 2013; 21(2):378391.

2. Aydınlatılmış Onam Kılavuzu. TTBUDEK Etik Çalışma Grubu. Ankara, 2013. 
3. Dünya Tabipler Birliği Helsinki Bildirgesi. JAMA, İncesu'nun 2001; 14,$8 ; 398-400$.

4. Kaya M. "Hekimin Aydınlatma Yükümlülüğü Ve Kişilik Hakkı İle İlişkisi”, Türkiye Adalet Akademisi Dergisi, 2012; 1 (3): 8.

5. Güzeldemir ME. Hasta bilgilendirmenin önemi. Sendrom Tip Dergisi. Mayıs; 2005; 1-28.

6. Aydınlatılıış Onam Hazırlama Ve Kullanma Rehberi. Ç.Ü. Tıp Fakültesi Hastanesi, Adana, 2005.

7. Hasta Hakları Yönetmeliği, Resmi Gazete, Tarih: 01.08.1998; Sayı: 23420 .

8. Özaydın Z. Bir Hasta Hakkı Olarak Özerklik Ve Aydınlatılmış Onay, Medikal Etik (Kuram Ve Uygulama Sorunlar1), Prof.Dr.Hüsrev Hatemi. (Ed). Tavaslı Matbaacılık, 1999; 3954.

9. Çullu, M. Hastaların cerrahi girişim öncesi dile getiremedikleri düşünce ve istekleri. Hacettepe Üniversitesi, Sağlık Bilimler Enstitüsü, Yüksek Lisans Tezi, Ankara., 2007.

10. Özcan FI. Tibbi Müdahalelerde Aydınlatılmış Onam. Marmara Üniversitesi, Sosyal Bilimler Enstitüsü, Yüksek Lisans Tezi, İstanbul, 2008.

11. İncesu E. Konya Seydişehir devlet hastanesinde yatan hastalarm, bilgilendirilme ve aydınlatılmış onam alma süreçlerinin değerlendirilmesi. Adli Bilimciler Derneği 1. Ulusal Sağlık Hukuku Kongresi, Marmaris, 14 Mayıs 2014.
12. Çağlayan $\mathrm{S}$, Tuncer BB. Ortodontide risk faktörleri ve hekim sorumluluğu. S.D.Ü Sağlık Bilimleri Enstitüsü Dergisi, 2013; 4 : 3 .

13. Jukic, M., Kozina, S., Kardum, G., Hogg, R., Kvolik, S. Physicians overestimate patient's knowledge of the process of informed consent: a crosssectional study. Med Glas (Zenica), 2011; 8:39-45.

14. Kalala WTPatients' perceptions and understanding of informed consent for surgical procedures, faculty of health sciences. Master of Medicine in Family Medicine, Johannesburg, 2011.

15. Erman B. Ceza Hukukunda Tibbi Müdahalelerin Hukuka Uygunluğu. Ankara: Seçkin Yayıncılık, 2003; 101103.

16. Aydın Er R, Özcan M. Akpınar A, Ersoy N. Ortopedide aydınlatılmış onama ait etik sorunlar: Kocaeli'den Bir Örnek. Türkiye Klinikleri J Med Sci., 2011; 31: 455-63.

17. Turla A, Karaarslan B, Kocakay M, Pekşen Y. Hastalara yeterince aydınlatma yapılıp-yapılmadığ 1 ve onam alınması durumunun saptanması. Turkiye Klinikleri J Foren Med., 2005; 2: 33-8.

18. Ghulam AT, Kessler M, Bachmann LM, Haller U, Kessler TM. Patients' satisfaction with the preoperative informed consent procedure: a multicenter questionnaire survey in Switzerland. Mayo Clin Proc., 2006; 81:307-12. 